\title{
The Folk Memory and Believe: One Candle Eradicate the Small Box; What Else?
}

\author{
Amro Abd Al Fattah Amara* \\ *Department of the Protein Research, Genetic Engineering and Biotechnology Research Institute, and the head of the \\ office of the Scientific Publishing, City for Scientific Research and Technological Applications, Universities and Research \\ Center district, New Borg El-Arab, Egypt
}

Received: : 12 April, 2017; Accepted: 10 May, 2017; Published: 20 May, 2017

*Corresponding authors: Amro Abd Al Fattah Amara, City for Scientific Research and Technological Applications, Universities and Research Center District, New Borg El-Arab, P.O. Box: 21934 Alex, Egypt, Tel No: +203-4593422; Fax: +203-4593497; E-mail: amroamara@web.de or amroamara@protonmail.ch

\begin{abstract}
The sculpture and handwritten records of the old civilization are treated unwisely through the history. Valuable scientific contents were not well documented or even photocopied. That was lead to the loss of valuable and critical knowledge. However, unwritten knowledge, which were transferred from generation to generation are preserved and still existed and can be recognized in the folks' daily practices. Some experience persons are in need to catch them. This mini-review is aim to highlight the historical timeline where the Human being has reported diseases and used tools to immunize himself through the history either by chance or by planed processes, including the vaccination. Most of the lost data from different known and unknown resources could be retrieved from the folk practices.
\end{abstract}

Keywords: Immunization; History; Folk; Timeline

\section{Abbreviations}

BCG:Bacillus of Calmette and Guérin; BG:Bacterial ghosts; CDR:Complementarily Determining Region; FMD:Foot and Mouth Disease; MG:Microbial Ghosts; MGC:Minimum Growth Concentration; MIC:Minimum Inhibition Concentration; RBC:Red Blood Cells

\section{Introduction}

The health as a word can be defined as: "the state of being free of physical or psychological disease, illness, or malfunction". In contrast, illness as word could be defined as: "impairment of normal physiological function affecting part or all of an organism". In addition to the physical and mental disorder, pathogens could cause illness. Pathogens are any disease-producing agent (especially a virus, bacterium or other microorganism). Our bodies are created perfectly to be able to resist different form of stresses and illness but for certain limits. The body is able to regenerate damaged tissues, bones, joint etc. However, the immune system is responsible for the defense against any foreigner could be specified as antigen(s). For more details about the immune system, refer to Amara (2016) or any textbook in the immunology [1].

There are strong evidences that the early Human beings were aware with issues related to the microbes ability to cause harmful illness and activities related to the health including the immunization [1-3]. Such knowledge came from his daily observation, thinking practicing and comparisons between factors give a healthy or unhealthy individual. He observes that many factors could affect on his heath. Some of such factors can be summarized in:

1.Live style [4-7].

2.Food [8-13].

3.Sleeping/ working/rest hours [14].

4.Gender [15-19].

5.Age [20-23].

6.The surrounding environment [8,24-27].

7.The sanitization [28].

8.The farm and domestic animals around [29-33].

9.Water quality [34-36].

10.The health of his parents as well as the health of his/her partner $[37,38]$.

11.Morale $[39,40]$.

Encyclopaedia Britannica describes the early medicine and folklore as "Human beings did not at first regard death and disease as natural phenomena. Common maladies, such as colds or constipation, were accepted as part of existence and dealt with by means of such herbal remedies as were available. Serious and disabling diseases, however, were placed in a very different category. These were of supernatural origin. They might be the result of a spell cast upon the victim by some enemy, visitation by a malevolent demon, or the work of an offended god who had either projected some object-a dart, a stone, a worm-into the body of the victim or had abstracted something, usually the soul of the patient. The treatment then applied was to lure the errant soul back to its proper habitat within the body or to extract the evil intruder, be it dart or demon, by counterspells, incantations, potions, suction, or other means. One curious method of providing the disease with means of escape from the body was by making 
a hole, 2.5 to $5 \mathrm{~cm}$ across, in the skull of the victim - the practice of trepanning, or trephining. Trepanned skulls of prehistoric date have been found in Britain, France, and other parts of Europe and in Peru. Many of them show evidence of healing and, presumably, of the patient's survival. The practice still exists among some tribal people in parts of Algeria, in Melanesia, and perhaps elsewhere, though it is fast becoming extinct. Magic and religion played a large part in the medicine of prehistoric or early human society. Administration of a vegetable drug or remedy by mouth was accompanied by incantations, dancing, grimaces, and all the tricks of the magician. Therefore, the first doctors, or "medicine men," were witch doctors or sorcerers. The use of charms and talismans, still prevalent in modern times, is of ancient origin. Apart from the treatment of wounds and broken bones, the folklore of medicine is probably the most ancient aspect of the art of healing, for primitive physicians showed their wisdom by treating the whole person, soul as well as body. Treatments and medicines that produced no physical effects on the body could nevertheless make a patient feel better when both healer and patient believed in their efficacy. This so-called placebo effect is applicable even in modern clinical medicine" [41].

This review contain some practices and stories from the folk prove that the early human beings have touch many scientific facts or at least have learned from the nature to treat diseases wisely and in more perfect ways.

\section{The Idiom "The Protection is Better Than the Treatment}

Through many generations, such idiom was well known. To establish safe live Human being has invented many daily practices and live different styles to protect him. Being always existed side by side with the farm and the domestic animals that might exceed the economic purposes to other ones. He observed that such animals have unexplained sort of protection to him. He believed that those animals could bring some sort of protection somehow. He might complain that those who have respected some animals are survived from certain illness.

\section{Human Beings and the Disease Control}

Human being has used successfully the tools around him from the environment where he is living [2,3,42-44]. In rich environment where there is no need to have extra tools to survive, the Human being become lazy, because the nature satisfies most of his demand. That is not a general role, where some rich environment encourages the invasion by others who aiming to control their resources. Invasion other places let the Human beings to learn from others. In such cases, the image takes another view. In the environments where there is a demand for developing tools to survive and to support his live, the Human being start to react and to develop civilizations. That could be the same in the case of the Human beings long history in fighting the diseases. Human being moved to live in a hotter environment observe that temperature responsible for the food spoilage. He learned how to preserve his foods. Alternatively, to use hot spices, salt; sugar (honey), onion, garlic and other natural products have strong antimicrobial agents.
In places where the continental meat each other and there are always groups movement, the Human beings invent, early, some tactics to avoid the transfer of harm diseases. That was happened by observing passengers aiming to detect any existed patients. The religious documents describes that Sarah and Abraham were stopped on the Egyptian border. In other separated areas, such practice could not be found. The environmental factor plays big roles in establishing certain awareness against infectious diseases.

Why he/she is survived? Why he/she is healthy? And vice versa; and many similar questions are raised early. Most of us should ask someone once "How he/she was dead?" "Was he/ she was thick?" If the answer; he/she was a smoker (or alcoholic), many of us will think upon his starting to practice such activities!

\section{Human beings and nature}

Part of the Human being knowledge was gained from the nature. He learned to use caves as houses, to get rest when he became thick, etc. It is logic that, the resources of the rich environments cause Human being to do less activity. Nevertheless, this did not affect on his intelligence by any mean. A prove for that might be in the fact that the civilizations were visited nearly every place in the earth at least one time. However, in general, Human being, overall the world, fix certain practices might be due to superior advises somehow he is get or due to a strong event learned he after some pain how to survive. In fact, in all of the Human being ages there were intelligent, super intelligent and wise individuals. They were so because they found solutions with tools might not satisfy the problem images. The first Human beings transferred their experiences orally from generation to generation. Such early knowledge contains some medicinal advices.

There are fine lines could be followed to prove that the early Human being has made good contribution concerning the control of the pathogens. He also prove that he understand issues such as deterioration, fermentation, degradation, the use of the microbes in certain applications related to the health improvement and immunization.

\section{Examples about Such Evidences, Which Prove the Early Human Beings Awareness, Could be Summarized in the Following Points}

1.The perfect mummification process by the Pharaoh. They are using wine and the plant resins in the mummification [1,45-48].

2.His early awareness by the fermentation process [49]. Human beings produce early, the wine, acetic acid, beverage, cheese, bread etc.

3.His awareness that hot spices could lasting the age of the food (have preservative activity). A fact could be observed nearly in the foods' of all of the hot regions.

4.His awareness with the different food preservation processes such as smoking, salting, sugaring, drying etc. In addition, in food fortification such as adding yeast, milk, cheese, meat, soup etc., to the bread and other forms, to increase their values, to improve 
their test and to lasting their shelf life [50].

5.His use for wine, acetic acid (by Moslem Sergeant) etc, as disinfecting agents.

6.His use of herbs to clean tooth and mouth.

7.His awareness with the different cleaning and sanitization processes such as the use of the water to clean the houses etc.

8.His awareness of the cleaning and sanitization activities using sand, the ashes, rice straw etc.

9.The awareness with the aromatherapy, incense, natural perfume etc [51].

10.The awareness about the spreading of the diseases and how to cut the spreading cycle.

In fact, there are quite more points could be added to prove the awareness of the early Human beings about the existing of the microbes. As described above, he did not see the fine structure of the microbes; but he should be able to see the fungal and the bacterial microbial colonies either in their solid or liquid foods (growth environment). As well as he should observe the changes made by the microbial growths such as the odder, the color etc. Even the Pasteur famous bottles were well known since ancient times. In Egypt there are different bisque containers still used until nowadays were used from unknown time as closed fermentation system particularly in the cheese aging $[1,47,48]$.

\section{The Early Oral Immunization Methods}

In Africa slotting and eating rooster as a part of the treatment of some diseases could be explained that it might has less virulence viruses (or particles) could immunize against other viral infections. In Egypt, until now a day, thick persons by either cold or certain illness are used to eat chickens cooked in boiled water and to drink their soup.

In the age of the molecular biology and nanotechnology there is a need for documenting such issues because the strong changes due to the fast progress in the technology development put strong press on such traditional methods. There is a general unawareness with the valuable scientific knowledge in the historical monuments of the old civilization. However many of such old civilization practices were transferred from generation to generation and were saved in the folk memory. Some avoid many of the folk practices without scientific judgment. However, others still believe in their power. Those old methods are the parents of the modern immunology and the vaccine technology and candles from the old civilizations.

This mini-review is aim to discuss the possible scientific evidences about the success of such old methods aiming to reintroduce them to the modern scientific community as well as to highlight the importance need for documenting them. This review suggests retrieving such lost documents in the medicinal science (and other important fields of science) by tracing the folk practice worldwide. Some valuable knowledge was survived only by the folks activities, in their story and practice over generations.
Nobody will accept in treating himself by active virus; but only if the treatment process(s) come from trusted persons prove success with his method(s). Another aim of this review is to pass the shy from discussing or documenting the folks contribution in the science progress such as the immunization as well as to give a timeline for the progress of the immunization through the history.

One should note that, this mini-review is not biased to the Egyptians/Africans/Middle east folks processes but only due to some awareness of the author with his region more than the other regions. However, that might encourage other to write about the old methods, which proved to be safe, practical and efficient; those, which are survived over ages. The only sham will be in losing documents and knowledge preserved for more than 8000 years.

\section{Early Human}

There are many books describes the early Human being as a creature did not has any sort of knowledge. In fact, most evidences prove that early Human being was knowledgeable and wiser to survive, to be healthy, happy, to have family to safe the nature and the earth resources etc. Early Human being when work as a hunter he learned to balance between his demand, the nature demand and the populations of the hunted animals. Few who are even believe that early human beings were more knowledgeable (e.g. mummification). In my own opinion and believe, there is nothing called primitive Human beings and civilized ones. The different was in the environment where they are lived.

\section{Noble Metals and Stones for Health Improvement}

Human beings had observed the differences between the noble metals (the gold and the silver) and the other metals, and that the noble metals did not rusting [52-55]. So, in Yemen where grate varieties of the noble stones are existed, human beings experiences tell that some stones affect on the human beings behavior somehow. Some stones bring relaxation, nervous, give power etc. I have followed this information and test some of the different types of them for nearly four years as in Figure 1.

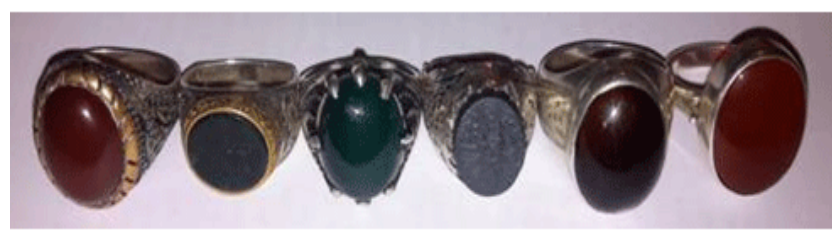

Figure 1: Noble metals and stones could improve health. Human beings get the experience that silver, gold (and other Noble metals) and noble stones have effect on his health. For that many are keen to have one of such rings in their hand.

The two in the right are from the Yemen which made a relaxation, the third from the right is from Iraq which keep you tension and if use it for long time you become aggressive, however it seems to give you certain power and has some healing effect. I observe that after putting it in an injured finger. The other three are from 
Egypt, which might be imported from outside the country and have some relaxation effect. In fact, I have suffered a lot from comments and questions about why you have such rings and for what you use them? The recent research proves that some metals have antimicrobial and anticancer effect. The skin absorb particles from the metals and the stones in nano scale and some believe in the vice versa reaction.

\section{Animal not only for Food! They can Cause Some Sort of Protection Against Illness!}

Quite enough evidences prove that human believe in that animals protect him somehow! That could be found in the old medicinal practice in Africa/Middle east. In addition, in Europe. In my own opinion, Human being give care to the farm and domestic animals due to their not only economic factors and joy but also to protect him. One of the most famous stories are the milkmaid and the cowpox. Another example is the large use of the cooked hen and its soup by individuals has illness (for many cases) in Egypt. Only hens grown in primitive and un-sanitized environment (not breeding ground chickens) are used and recommended by the folk. Uneducated individuals are able to differentiate between two of the domestic hen. And they preferred the one which is more immunized! One should remark that our modern cities omit such chances. Did some of the new elevated diseases were existed before but we, somehow, were protected due to our early lifestyle and now we are losing such protection!, due to the excessive modernization and sanitization. At least one should has an access to farms, desert, wild nature etc.

If someone become dead or ill questions arises, such as did he has been dead normally? Did he was sick? How he become sick? Such questions build a folk and public database about what we should do and what we should not to do. That will keep us healthy.

One of the earliest documents about the existence of a physician might came from Egypt. For example, Imhotep the chief minister to Djoser (reigned 2630-2611 BCE), the second king of Egypt's third dynasty in the 3rd millennium BCE, who designed one of the earliest pyramids, the Step Pyramid at Saqqārah. The Egyptians were documented many diseases and different kind of treatments. In Egypt, rabies and poliomyelitis (polio) were known (rabies, hydrophobia, lyssa, madness -- (an acute viral disease of the nervous system of warm-blooded animals (usually transmitted by the bite of a rabid animal); rabies is fatal if the virus reaches the brain) (poliomyelitis, polio, infantile paralysis, acute anterior poliomyelitis -- (an acute viral disease marked by inflammation of nerve cells of the brain stem and spinal cord). Figure 2 shows some bottles (exceed Pasteur bottles with thousands of years) represent, some kind of scientific activity. In addition, perhaps some research!

Aiming to lasting his life and to maintain his corpus after dead for the second life, and they believe that the incorrect corpus might not be able to return to the second life. Human beings do a lot to safe his body and to repair any damaged part.

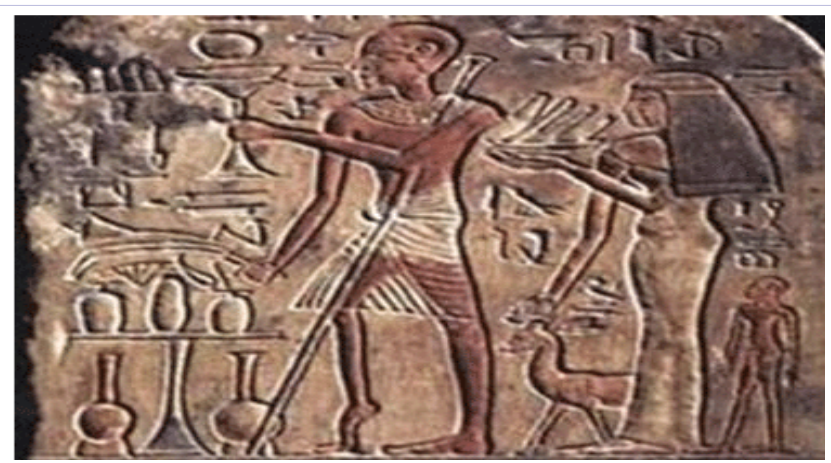

Figure 2: Pharaoh Draw on a stone describe the man with leg due to the infection with poliomyelitis (polio) [56].

He learned to avoid any kind of infections or strong injury might deform his body. In my opinion the image of the poliomyelitis person is describes not only the disease but also trials or some sort of pray to retrieve the effected leg to its normal case. At least there were some awareness and might be some research and trials.

The symptoms of many diseases are well known. The bite of the dog is known to be dangerous. In Egypt folk treats dog bites by putting the heir ash (from the same dog) on the surface of the injury!

The Greek historian Herodotus born 484 BC stated that every Babylonian was an amateur physician, since it was the custom to lay the sick in the street so that anyone passing by might offer advice $[57,58]$. The history, the literatures prove that the physician as a job was existed in all ages. The early Human being was more relaxed, has more time to think, to join and to compare between observations from his/other live style. It was clear that he was able to monitor changes happened. If a disease is emerged, he successfully link between such disease and any of the changes happened in his life style. For example he prefer to married than to prostitution after observing the diseases transition by such activity.

Even he go further steps and give his life some philosophical view such as with Thucydides (430 BC- Figure 3)

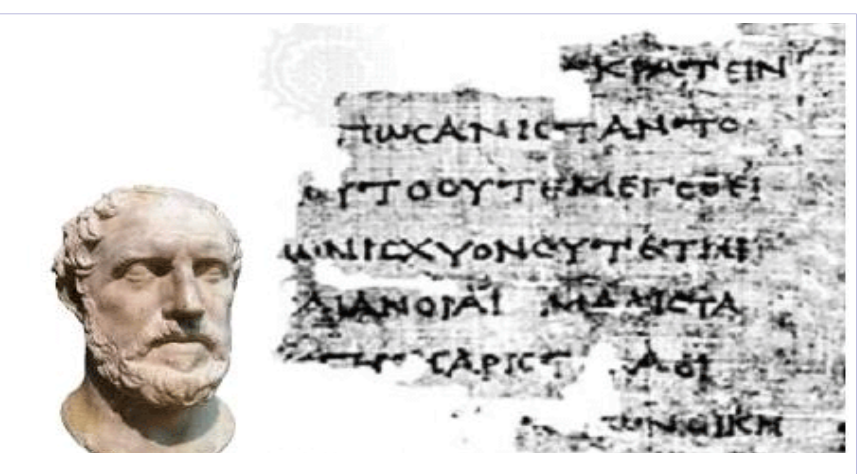

Figure 3: The head of Thucydides and part of his book where he describes the political case of Athena as the plague. The old Human beings have more time to go deeper and to think in relaxed mode [60]. 
who describe a plague in Athens; he wrote that only those who had recovered from the plague could nurse the sick because they could not contract the disease a second time [59]. He clinically notes the degeneration of the Athenian body politic.

From Encyclopaedia Britannica “The city's highest ideals are articulated in the funeral oration that Thucydides attributes to the Athenian leader Pericles; its realpolitik is brutally illustrated in the city's treatment of the inhabitants of the island of Melos. In the famous "Melian Dialogue," the Athenians demand that the hitherto neutral Melians join their confederation. They offer no justification of their demand beyond their power to enforce it, warning the Melians against having any hope in portents or oracles. When the Melians refuse, the Athenians send a force so strong that the Melians surrender unconditionally, whereupon the Athenians massacre all the men of military age and sell the women and children into slavery" [60].

\section{Utilizing the Old Civilization Knowledge}

Through history, knowledge has been transferred with different ways either peacefully or with some pains. It is clear that after the invasion of Nablion to the Middle East particularly to the Egypt; a lot of the traditional practice were gained, documented and transferred abroad. Pharaoh civilization, which is one of the old known civilizations and might be the oldest one located in the central of the world. Egypt was a pool where experiences are collected from everywhere, improved or modified and new ones are developed. The French crop uses a strategy based on documenting everything as it is precisely. That was helpful particularly in the knowledge transfer. Also, the traditional medicinal Arabic books, which are describe many tactics for improving health, protection and curing from different diseases, which in some time contain unexplained tools, all that were in the hand of the French. Moreover, they succeeded to reintroduce the importance of the medicinal advices of the ancient Egyptian civilization, the Pharaoh (including some of their medicinal applications). Additionally, the Arabic transferred knowledge from nearly all places, which transferred spontaneously to Egypt [1].

\section{Fermented and Aged Foods}

Perhaps the oldest known reservoir, which allows correct and safe fermentation including safe air transfer, was an Egyptian invention for producing old cheese.

Traditional foods such as beverages, salty fishes, yogurt, different types of cheeses and so on were used since olden times (Figure 4) [61]. Such food structures contain different types of useful bacteria. It might be that the first real use of food containing Probiotics was the fermented milk [62]. Human beings were learned that fermented milk has a good taste and can stay longer without spoilage. After being dry, it get another taste and could resist the spoilage [63-65]. The climatic conditions, for sure, favored traditional sour milk or cultured dairy products such as Kefir, Koumiss, Leben and Dahi as claimed by Hosono (1992) [62]. In Europe selected places were used for better cheese production, usually enable fresh dry cold air. Public distribute stories about the origin of some types of Probiotics and that some have religious origin, such as the origin of the Kefier [61].

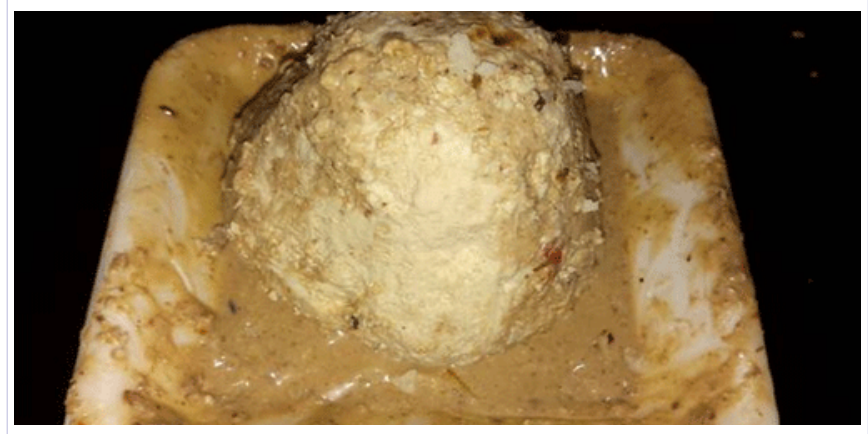

Figure 4: Aged cheese "Mish" might be the first static continuous fermentation process in the earth. The single container stay for generation or until damaged.

Another different practices related to the probiotic subjects could be found. By tracing, such information in both of Egypt and Morocco peoples till nowadays asking some persons usually known for their kindness and are noble in their attitude to give them from their saliva and use that for a treatment. In my family, the people used to come to visit one of my uncles to give them some of his saliva as I has informed from his sons. In Morocco, I have informed that some families still practice that. Usually, they do that without earning money. It is nothing but a primitive (or might be an advanced) way for getting a benefit from the microflora of healthy individuals. Alternatively, peoples asking those men to showing date with their mouth, take it, and feed it to their infants. Amara, (2012), describe some of the Probiotics used by the Pharaoh civilization, which the Egyptians still use nowadays [66]. They include milk, seeds, pre-grown seed (source of melatonin) sub-rotten fish, and some other products. However, it might be that Ilya Ilyich Metchnikoff, the Nobel Prize winner in medicine in 1908, at the Pasteur Institute was the first who spotted the effect of what is called as probiotic. He linked the health and longevity to the ingestion of bacteria present in yogurt [63,64]. Food and Agriculture Organization of the United Nations/ World Health Organization (FAO/WHO, 2001) endorsed by the International Scientific Association for Probiotics and Prebiotics, defined Probiotics as 'Live microorganisms which, when administered in adequate amounts, confer a health benefit on the host $[67,68]$.

There are evidences that ancient civilizations have some foods and practice could improve the immune system. They are either knowledgeable more than we expected or they find solutions by chances. They even do that in the time where the weather exchanges. They believe that the whether exchange brings illness.

In Egypt, there is a celebration between two seasons ('Sham ennisim' at the beginning of spring). In that day the Egyptian, eat salted sub-rotten fishes, which contain of both probiotic and antibiotic. The mild rotten fish is excessively 
subjected to salt (Figure 5). Such salting process will kill most of the existing microbes including pathogenic and non-pathogenic hence will let them to be as an oral vaccine upon their eat.

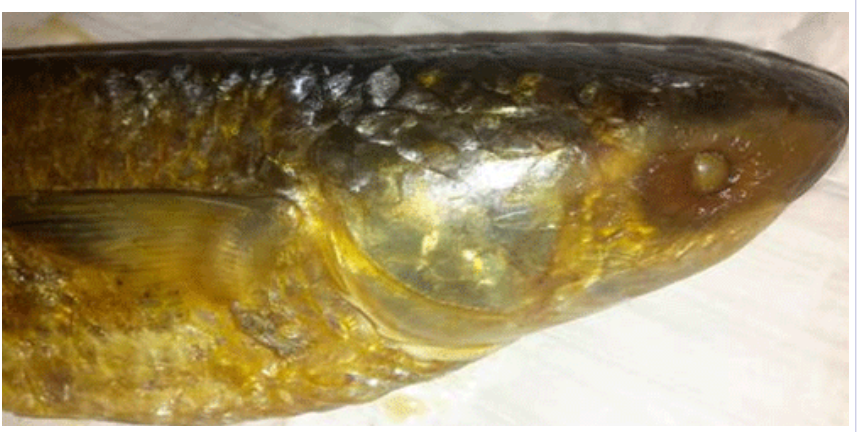

Figure 5: Aged see fish left in the air and sun until start to route and then transferred to a salt container and kept for a time. Some other alternative methods are existed.

\section{Natural Microbial Ghosting}

Like any creature, each microbe has a life cycle ends with the death. The microbes' cell walls after their death could stay longer and resist decaying. However, due to natural decay, environmental effect, enzymatic activity of other microbes, or any other expected mechanism, that can lead the microbes to loss their cytoplasm or become inactive. For that, cell ghosts and microbial ghosts are produced daily in our bodies (inside, or outside). They are produced in the lung, in the stomach, in the surface of our skin, in our aged food and so on. So dead and microbial ghost are natural phenomenon. They play different roles in immunization.

In fact, the two used methods now a day for bacterial ghosts preparation are extracted from the nature. The first one the $E$ lysis gene method is based on the bacteriophage $E$ lysis gene. Phages could found everywhere and could work at any time and in various conditions. Therefore, we utilize the phage ghosts everyday orally or through other routes. That cause natural immunization. The second one the Sponge like protocol which is based on the critical concentration of some chemical compounds are also happened due to the effect of any chemicals, drugs, acid, natural products etc., could kill the microbes without deforming their 3D structure. Even the saliva in the mouth contains lysozyme, which kill most microbes. In fact, saliva turns microbes to ghosts. Microbes when interred in small amount could be controlled by the saliva lysozyme. Most of us should receive an advice from some old person "eat slowly and chew your food well!" It is a perfect advice to immunize us every day. Any microbes inter through the mouth will be turned due to the activity of the saliva lysozyme to ghosts and hence will immunize [48].

\section{The Source of the knowledge Through History Concerning the Diseases and the Immunization}

By analysis the possible resources for the disease control knowledge gained through history, one could concluded that there are five main resources for the knowledge concerning the disease control.
1-The accumulation of the knowledge by different resources e.g.: documentation, practicing, education, written, oral.

2-The continuous improving for the used tactics by using existing tools or importing additional materials from other places.

3-The continuous observation and thinking, the trial and error, which are the primitive steps in the modern research activities.

4-Unexpected result happened either by chance or by planed experiments.

5-Religious documents and orders.

\section{Folk and the Food}

\section{Camel Milk}

In the North Africa including Egypt there is a general respect for the milk [69]. Some religious order the mothers to give their infants particular years of lactations. The milk contains many vital elements, vitamins, amino acids, sugar etc. It is the only known complete food. In addition, it contains antibodies. Moslems consider different infants lactating from the same mother as brothers and forbidden the marriage between them. That because they believe that, they become similar due to the lactation from the same mother and if they get married they will have unhealthy children due to that they are similar till the brother level! This might be a nonscientific early understand for the epigenetic!

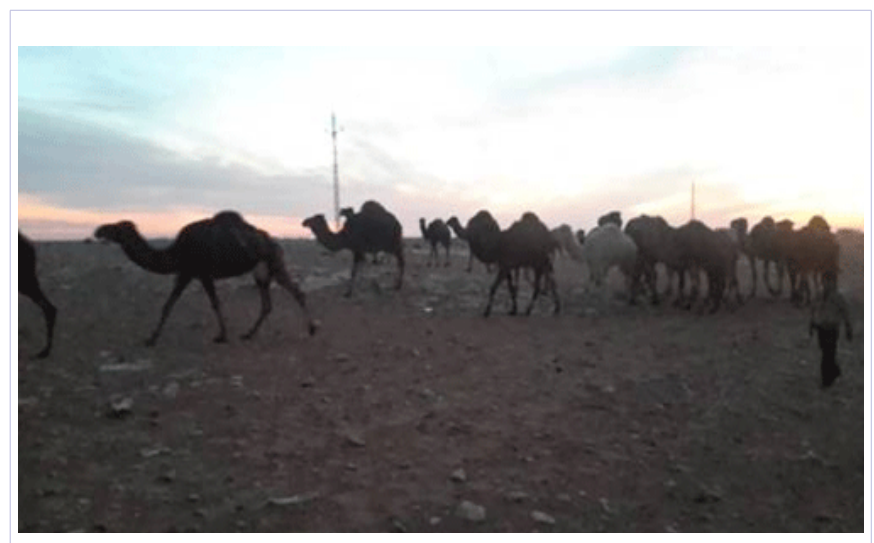

Figure 6: Camels coming back to home from the desert at the end of the day. There are a general believe in the power of the camels milk and particularly if it was feed on natural herbs. While the camel urine is also contain the extracts of the plants (it feed on) also urine is used for treating illness. In most cases, milk and urine are mixed.

In my area "Alexandria," and Matrouh the lay people trust a lot on the camel's milk. It could be used for many purposes (Figure 6,7). However, the only weak point that they believe that one should drink it just after milking fresh and still has the animal temperature. Few who accept to buy packed camel milk! 


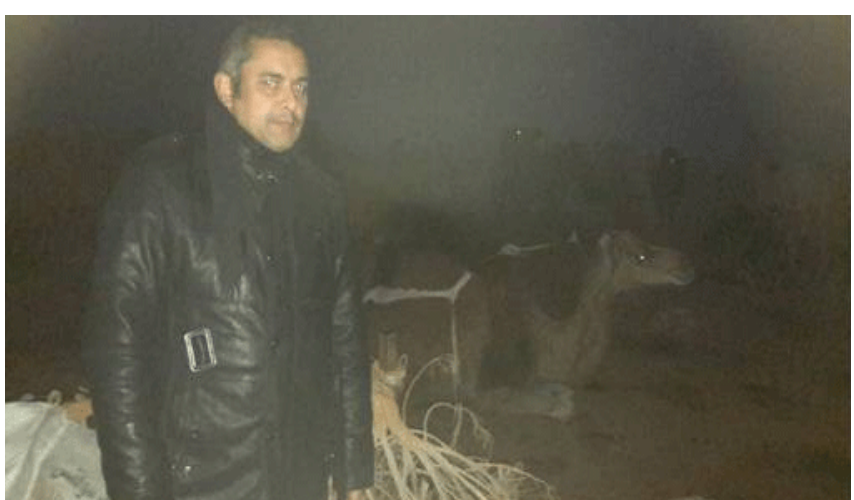

Figure 7: Freezing from the desert air and cold at the night with camels. The camel live in wild desert are preferred. In addition, some places are still secret but only for few who know such science. By their feeding on the wild desert plants, live naturally, even sleep in open land without any sort of protection or any afraid from their losing or stilling, that might made differences!

\section{Camel Urine}

Mixing the camel milk and its urine is a well-known treatment method within Moslems particularly the Bedouins to treat liver and stomach illness (e.g. virus C). Some recommended drinking the milk directly after the milking alone or after mixing it with the camel urine (Figure 8). Forty days is recommended.

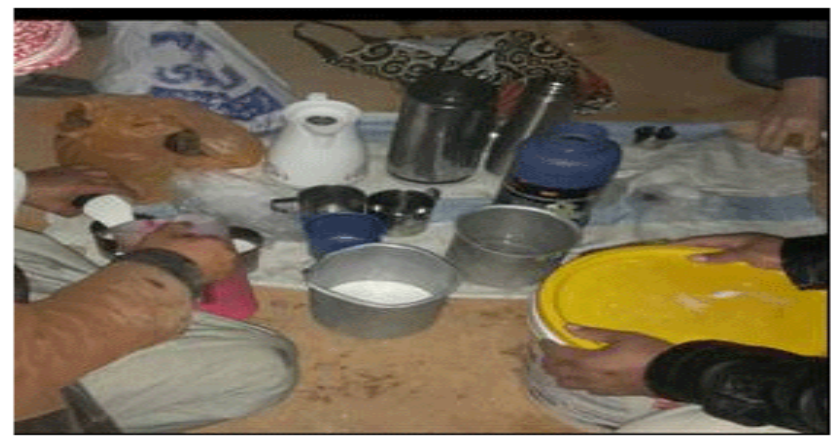

Figure 8: Bedouins mixing the urine with the just milked camel milk. The patients are many and each wait until he/she gets the chance to drink such mixture.

I have heard a story telling that women informed by her doctor that she would not be able to have children. She becomes able to be pregnant after drinking for forty-day fresh camel milk.

Some believe in its power in regenerating cells, remove fibrosis and destroy tumors. I am personally has treat myself with the camel urine and its milk for short period. It is able to strengthen the body and give one some additional power. Fasting all the day and drink the camel milk before the sunrise and after the sun going will give the best result.

One should describe that the memory of the Bedouins tell that pregnant women should not drink the camel milk. They reclaim that it lasting the pregnancy to more than nine months!

Early Human beings gone some early advanced steps, by pass the tedious extraction and purification process, and drink the milk and the urine of the animals, which feed on medicinal plants or in poisonous plants.

The old story describe that human even drink the milk of the lioness to have males and strong children. In Egypt the folk still advice the mother has a children suffer from cough to drink the donkey milk.

The literatures describes that Mamlouks (the strongest slave kingdom governed Egypt, Sham and some other Arabic countries) were drinking the horses milk. There is a believe that the milk of the strong animal should give power. In the ancient Arabic history born children did not allowed to grow in the cities but transferred to the Bedouins in the desert to be more tuff and more stronger. Many nowadays are interesting to investigate by themselves the Bedouins lifestyle [70].

Nowadays camel milk and urine prove to have some valuable properties such as

1.In insulin signaling [71].

2.The antiplatelet activity of camel urine [72]

3.The nematicidal effects of camel milk [73].

4.The camel urine components display anti-cancer properties [74].

5.Camel milk peptide improves wound healing in diabetic rats [75].

6.The influences of camel milk on the immune response of chronic hepatitis patients [76].

7.Nutritional and Therapeutic Characteristics of Camel Milk in Children [77].

\section{Mummification and the embalming processes}

From the old stories and literature, one could observe the presence of perfect understand for the diseases and the deteriorating agents. Concerning the diseases fitting in general there were some common protection tools could be extracted from each of the folk, the history and the observations.

The beginnings of the art and techniques of embalming are associated principally with ancient Egypt, where, as in parts of Asia and South America, a dry soil and climate encouraged its development [78]. The early practice of wrapping the dead in cloth and burying them in charcoal and sand beyond the reach of the Nile waters preserved the corpses, which retained form and features for a long period. A belief in immortality and physical resurrection was central to Egyptian religion. Central to the latter was the belief that when all of the elements that were present in life-soul, name, shadow, heart, and body-were reunited, the person would be resurrected.

In the traditional medicine, the wine was used to disinfect injuries. Perhaps the Arabic Moslem surgeon was used the acetic acid instead of the wine due to religious restrictions. Additionally one of the folk well-known wound disinfectants is 
the herbs and the wood ashes. In Egypt in some cases ashes still used by folk till now.

\section{Inoculation}

Process of producing immunity and method of vaccination that consists of introduction of the infectious agent onto an abraded or absorptive skin surface instead of inserting the substance in the tissues by means of a hollow needle, as in injection [79-83].

One should never forget that both of the vairolation (inoculation) and the use of the cowpox to immunize against the smallpox are derived from the folk memory, experiences and stories. Smallpox pustules were either inhaled into the nostrils or inserted into small cuts in the skin were reported by herders in Africa and for Human beings protection in the Middle East. In fact, the folk believe that there are strong evidences that great civilizations other than the Egyptian civilization are existed in Africa, Yamane and Middle East. Other believes that they all are under the Egyptian empire. One could trace their practices which still used by individuals in these area succeeded to protect themselves and their animals against fetal diseases such as the smallpox, cowpox and sheep pox. The clinical trials in such ages were represented in the success and the acceptance of the used practice. That guarantees its transfer from generation to generation. Some of such practice appears to be dangerous but in fact, they prove to be safe such as the inoculation of the smallpox [1]. Of the common vaccines, only smallpox vaccine is routinely inoculated. The term inoculation is also commonly used more broadly to mean any introduction of antigenic substances into the tissues. $1000 \mathrm{AD}$; Inoculation documented from China. Inoculation was reportedly practicable in India also. $1500 \mathrm{AD}$; Chinese and Turks reports suggest that the dried crusts derived from smallpox pustules were either inhaled into the nostrils or inserted into small cuts in the skin (a technique called variolation). Also reported by herders in Africa and for Human beings protection in the Middle East. 1600; Documented evidences of practice of inoculation (variolation) from India. 1718; Lady Mary Wortley Montagu, the wife of the British ambassador to Constantinople, observed the positive effect of the variolation on the native population and had the technique performed on her own children. 1767; Dr. Holwell gave a description of practice of inoculation in India to College of Physicians in London. 1774; Benjamin Jesty did experiment on his wife and two children by injecting cowpox matter [1].

The letter by Lady Mary Wortley Montagu to Sarah Chiswell, dated 1 April 1717, from the Turkish Embassy describes this treatment "The small-pox so fatal and so general amongst us is here entirely harmless by the invention of ingrafting (which is the term they give it). There is a set of old women who make it their business to perform the operation. Every autumn in the month of September, when the great heat is abated, people send to one another to know if any of their family has a mind to have the small-pox. They make par- ties for this purpose, and when they are met (commonly fifteen or sixteen together) the old woman comes with a nutshell full of the matter of the best sort of small-pox and asks what veins you please to have opened. She immediately rips open that you offer to her with a large needle (which gives you no more pain than a common scratch) and puts into the vein as much venom as can lye upon the head of her needle, and after binds up the little wound with a hollow bit of shell, and in this manner opens four or five veins. The children or young patients play together all the rest of the day and are in perfect health till the eighth. Then the fever begins to seize them and they keep their beds two days, very seldom three. They have very rarely above twenty or thirty in their faces, which never mark, and in eight days time they are as well as before the illness. There is no example of any one that has died in it, and you may believe I am very well satisfied of the safety of the experiment since I intend to try it on my dear little son. I am patriot enough to take pains to bring this useful invention into fashion in England, and I should not fail to write to some of our doctors very particularly about it if I knew any one of them that I thought had virtue enough to destroy such a considerable branch of their revenue for the good of mankind, but that distemper is too beneficial to them not to expose to all their resentment the hardy weight that should undertake to put an end to it. Perhaps if I live to return I may, however, have courage to war with after them.

\section{Living Close to the Farm and the Domestic Animals}

The modern vaccine start with simple observation, which was well known within farmer but less explained until a physician explained it scientifically. However, transferring knowledge of effective method even non-fully proven ones safely lead to that such knowledge has reach some educated one could explained it scientifically. The milkmaid who infected in their hand by cowpox is protected against smallpox and she was happy because her face will be beautiful. She starts to song even. A physician heard this song "I shall never have smallpox for I have had cowpox. I shall never have an ugly pockmarked face." The cow name is "Blossom". The physician start to investigate the case, then he concluded that the infection with cowpox will protect against the smallpox. He made manual infection from arm to arm by the lymph node."

By tracing another practice by milkmaid the old literature there is evidence that such practice are well known [1].

'Where are you going, my pretty maid?'

'I'm going a-milking, sir' she said.

'May I go with you, my pretty maid?'

'You're kindly welcome, sir' she said.

'What is your father, my pretty maid?'

'My father's a farmer, sir' she said.

'What is your fortune, my pretty maid?'

'My face is my fortune, sir' she said.

'Then I can't marry you, my pretty maid.'

'Nobody asked you, sir' she said [1]. 


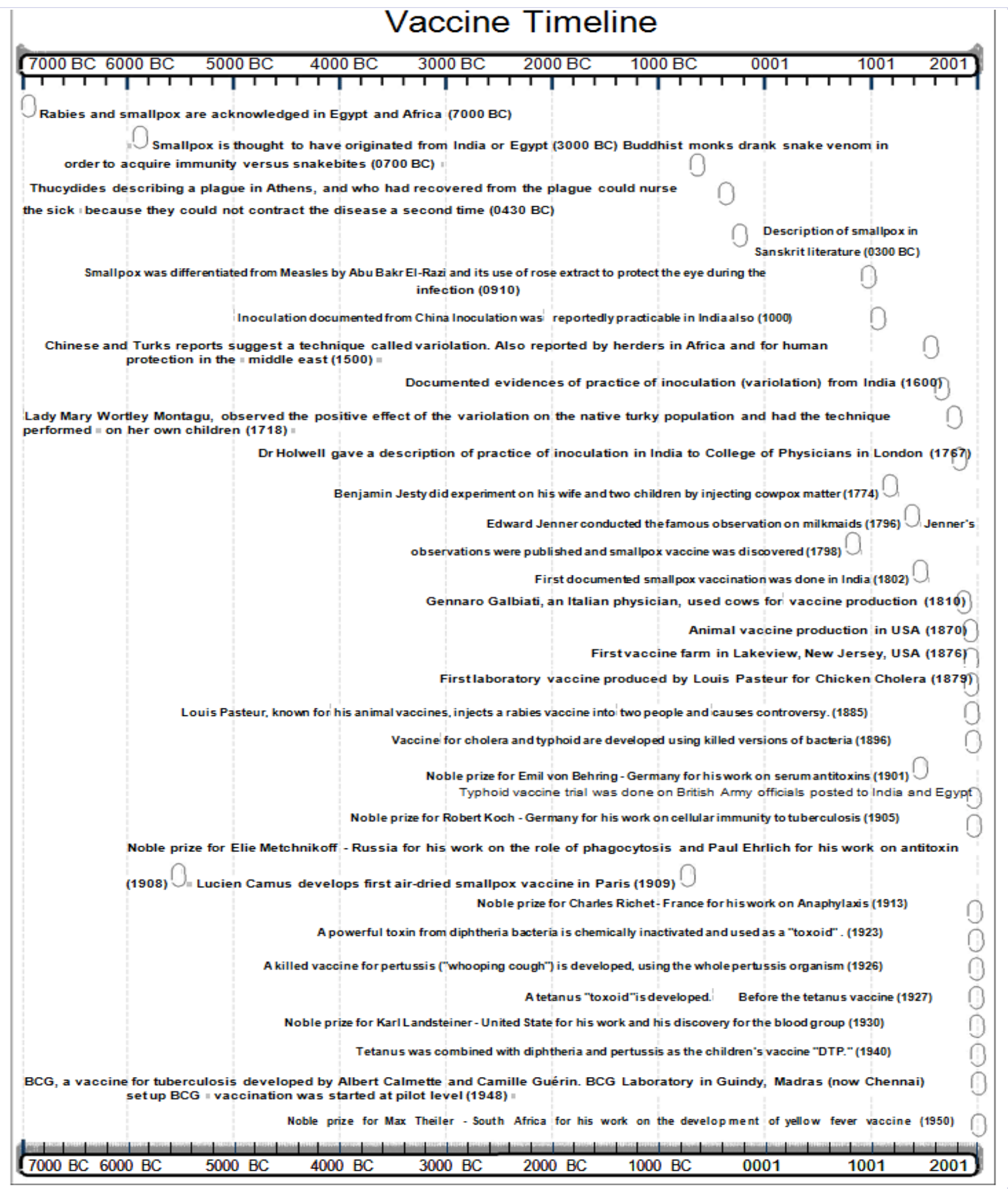

Figure 9: Vaccine and immunization time line 1 


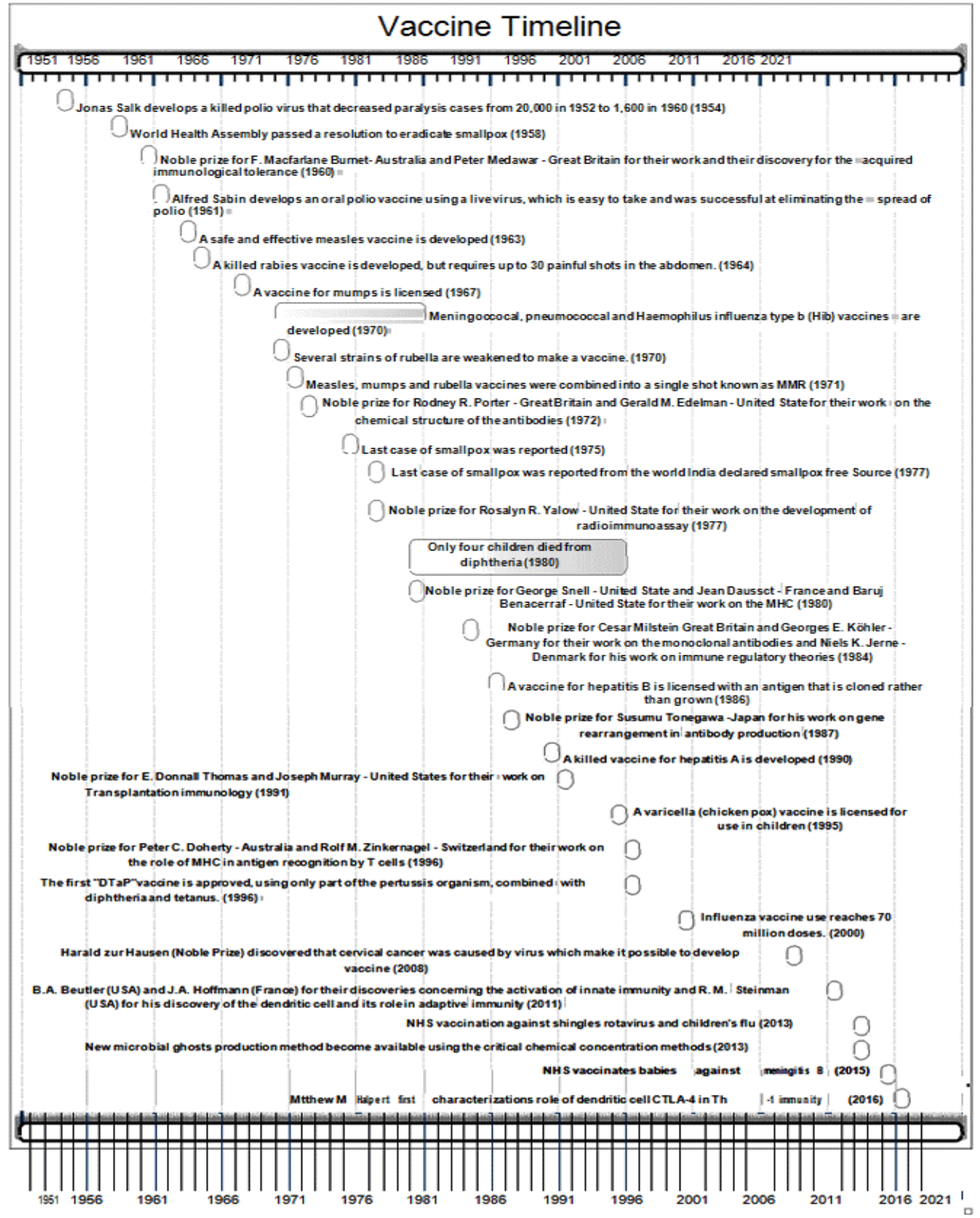

Figure 10: Vaccine and immunization time line 2 
There is documentary evidence of the use of the inoculation technique against smallpox by nomadic herders in Africa (e.g.: Tulani). Somebody is in Africa mentioned inoculation against sheep pox as long ago as the 16th Century. Apparently, the Human beings variolation was attempted in Egypt, Sudan, China, east Africa, or India from undocumented time $[1,84]$.

In the French language, a term was used to refer specifically to inoculation with sheep pox, clavélisation, from the French word for the disease, clavelée.

Inoculation with smallpox was by using only Human beings material, serous matter from pustules (A small-inflamed elevation of skin containing pus; a blister filled with pus) and scabs taken from a subject with a mild form of the disease.

Inoculation with unspecific virus aiming to immunization against the smallpox was made by using the cowpox by an English doctor, Edward Jenner (1749-1823) [84].

The inoculation with unspecific virus but have the same symptoms (but non-fatal) the cowpox which proposed by Jenner in 1798 prove to be more efficient but also safer [84].

Lombard et al wrote "At the beginning of the 19th Century, Jenner's vaccination procedure rapidly spread around the world, supported by governments favourable to a measure that could reduce the devastating effects of epidemics on their populations [84]. The President of the United States of America (USA); the Tsar of Russia; the King of Sweden; the Emperor of France, Napoleon I; and the Pasha of Egypt, Ali Mohammed, to mention but a few, were greatly enthusiastic about the vaccine and actively promulgated it, in some cases, as with Napoleon I in 1812, going as far as to make it compulsory in the army, and even in society as a whole. When it came to putting these plans into action, however, it was of course quite a different story".

In Europe, efforts for immunizing by inoculation were made for the sheep pox. Sheep pox is a virus, which is close to smallpox in Human beings. Belgian physician Willems made effort with the bovine contagious pleuropneumonia disease, which was inoculated by using the ancient civilization practice at 1853 . The inoculation was made in the base of the tail of the animals with a small amount of the isolated infective material [84].

The treating of the smallpox in such age eradicating it before fully clarifying the origin and behavior of poxviruses and their vaccines throughout history [84] (Figure 9,10).

\section{The Toussaint and Pasteurian Era, the Real Turn in Treatment}

Apparently, the Toussain and Pasteurian era is depend on the microbial attenuation, which is a trend; attract many of the scientists before Louis Pasteur. Apparently, the target was the anthrax, which was subjected to many form of attenuation to use it as vaccine. In 1876, the French veterinarian Henri Toussaint (1847-1890) cultured a causal bacterium of fowl cholera in neutralized urine, described two years later by Perroncito (and subsequently known as Pasteurella avicida or gallicida, and now as P. multocida) $[1,84]$. The hen survived inoculation with the 'forgotten' cultures and even became resistant to a subsequent, virulent inoculation. It was in fact an empirical trial to attenuate the culture by re-seeding the medium at longer intervals devised by Emile Roux with the help of a system of continuous oxygenation to accelerate the aging process [84]. John Burdet-Sanderson and William Greenfield (England, in 1878), by re-seeding the culture at $35^{\circ} \mathrm{C}$ succeeded to attenuate the virulence of the strain without affecting its immunizing potential. In 1880, Henry Toussaint proposed that if animals were vaccinated with blood heated at $55^{\circ} \mathrm{C}$ they could then survive an otherwise lethal inoculation. He successfully immunized five ewes using this technique.

Toussaint admires Pasteur, in the year 1879. He isolated the microbe of "cholera des poules" (Pasteurella) and gives Pasteur this new microbe. Pasteur used this microbe for his research about reducing the virulence by successive subculturing. In 1880 his publishing on July 12 at the Academy of science, Toussaint presents his successful results with an attenuated vaccine against antherax. He used dog's sheep and vaccine, which he has reduced off virulence by chemical manner [85]. The fowl cholera culture, which might be attenuated chemically and then left as Pasteur, describes more longer to be aged. The chickens become ill, but not dead. And after they are given active viable culture, they were survived and become protected. Following his teacher, in 1881, Louis Pasteur undertook his still famous trial at the farm in Pouilly-le-Fort, near Paris. In the presence of an extensive public consisting of farmers and veterinarians, he compared the behavior of vaccinated and unvaccinated sheep. Initially, his vaccine had consisted of a culture attenuated simply by heating same as what done by Henry Toussaint. However, Pasteur's disciples persuaded him to take the precaution of using an attenuated culture also containing an antiseptic known to inhibit the formation of spores (this was 'the secret of Pouillyle-Fort'), [84]. For more details about the vaccine history refer to Amara (2016).

\section{Conclusion}

From the old history and during the Human beings living on the earth several tactics and practices were gained and transferred from generation to generation.

In fact, there were great civilizations in different places in the earth. Such civilizations left different daily practices concerning the health, medicine, immunization etc. Recently, and due to many factors of the modernization and excessive sanitization there are a general ignorance for the importance of such facts and knowledge. It is important to document the entire old information particularly those which not written in any document but protected only by transferring them from generation to generation by the folk. Such tools and practices are saved over ages only because they are proved to be efficient. In addition, some become in the hand of little population and there is a great afraid from losing such knowledge. One perfect example was the smallpox, which controlled by the folk practice "inoculation" and eradicated by the folk memory and stories "the story of the cowpox and the milkmaid".

The message which this review is addressed is that our 
knowledge is comes from the accumulation of the knowledge of several civilizations. Some lost documents and Human beings experiences could be retrieved from the folk stories, practices, awareness etc. It is important to document the folk historical experiences before valuable knowledge are disappeared.

\section{References}

1. Amara AA. Vaccine against pathogens: A review and food for thought. SOJ Biochemistry. 2016;2(2):1-20. doi: 10.15226/2376$4589 / 2 / 2 / 00108$

2. Rivers TM, Ward SM, Baird RD. Amount and Duration of Immunity Induced by Intradermal Inoculation of Cultured Vaccine Virus. J Exp Med. 1939;69:857-866

3. Stern AM, Markel H. The history of vaccines and immunization: familiar patterns, new challenges. Health Aff (Millwood). 2005;24(3):611-621

4. Andre F, Van Damme P, Safary A, Banatvala J. Inactivated hepatitis A vaccine: immunogenicity, efficacy, safety and review of official recommendations for use. Expert Rev Vaccines. 2002;1(1):9-23

5. Kohut ML, Cooper MM, Nickolaus MS, Russell DR, Cunnick JE. Exercise and psychosocial factors modulate immunity to influenza vaccine in elderly individuals. J Gerontol A Biol Sci Med Sci. 2002;57(9):M557562

6. Michalsen A, Hoffmann B, Moebus S, Backer M, Langhorst J, Dobos GJ. Incorporation of fasting therapy in an integrative medicine ward: evaluation of outcome, safety, and effects on lifestyle adherence in a large prospective cohort study. J Altern Complement Med. 2005;11(4):601-607

7. Rosenthal SL, Rupp R, Zimet GD, Meza HM, Loza ML, Short MB, et al. Uptake of HPV vaccine: demographics, sexual history and values, parenting style, and vaccine attitudes. J Adolesc Health. 2008;43(3):239-245. doi: 10.1016/j.jadohealth.2008.06.009

8. Development of Supplementation Strategies for Milk-Producing Animals in Tropical and Sub-Tropical Environments. Proceedings of a meeting. Malang, Indonesia, 24-28 March 1997. Prev Vet Med. 1999;38:81-230

9. Centers for Disease Control and Prevention (CDC). Women with smallpox vaccine exposure during pregnancy reported to the National Smallpox Vaccine in Pregnancy Registry--United States, 2003. MMWR Morb Mortal Wkly Rep. 2003;52(17):386-388

10. Centers for Disease Control and Prevention (CDC). Smallpox vaccine adverse events among civilians--United States, February 25-March 3, 2003. MMWR Morb Mortal Wkly Rep. 2003;52(9):180-181

11.Amara A. The inevitability of balanced lives: genes-foods-actioninteractions. IIOBJ. 2013;4(2):1-27

12. Amara AA. Opportunistic pathogens and their biofilm Food for thought. Science against microbial pathogens: communicating current research and technological advances. Microbiology Book Series. 2011;3:813825

13. Amara AA. The philosophy behind exo/endo/existing antioxidants and our built-in oxidant and antioxidant system. Pharmazie. 2010;65(10):711-719

14. Muraz. [Current medical problems in French West Africa; difficulties in the organization of the new School of Medicine of Dakar; works on urban hygiene at Bamako, Sudan; the campaign against sleeping sickness in French West Africa and its developments]. Sem Hop. 1951;27(43):1877-1882

15. Kaltman S, Tractenberg RE, Taylor K, Green BL. The smallpox vaccine: a multidimensional model of choice. Biosecur Bioterror. 2006;4(1):6473

16. Kennedy RB, Ovsyannikova IG, Pankratz VS, Vierkant RA, Jacobson RM, Ryan MA, et al. Gender effects on humoral immune responses to smallpox vaccine. Vaccine 2009;27(25-26):3319-3323. doi: 10.1016/j. vaccine.2009.01.086

17. McNeil MM, Chiang IS, Wheeling JT, Zhang Y. Short-term reactogenicity and gender effect of anthrax vaccine: analysis of a 1967-1972 study and review of the 1955-2005 medical literature. Pharmacoepidemiol Drug Saf. 2007;16(3):259-274

18. Ramon G, Richou R, Thiery J, Gerbeaux C. [Comparative action of cortisone and anti-E.coli vaccine on the specific immunity engendered by Staphylococcus anatoxin]. C R Hebd Seances Acad Sci. 1952;234(22):2131-2133

19. Winkler AS, Mayer M, Ombay M, Mathias B, Schmutzhard E, JilekAall L. Attitudes towards African traditional medicine and Christian spiritual healing regarding treatment of epilepsy in a rural community of northern Tanzania. Afr J Tradit Complement Altern Med. 2009;7(2):162-170

20. Smallpox vaccine: who should get it? Child Health Alert. 2002;20:1-2

21. Does eating cheese have a tendency to increase a person's cholesterol? Would eating a hard, sharp, aged cheddar cheese be more harmful than eating cottage cheese or a soft cream cheese? Mayo Clin Health Lett. 2009;27:8

22. Achenbach P, Barker J, Bonifacio E. Modulating the natural history of type 1 diabetes in children at high genetic risk by mucosal insulin immunization. Curr Diab Rep. 2008;8(2):87-93

23. Altemeier WA, 3rd. A pediatrician's view. Some science and history behind our vaccine schedule. Pediatr Ann. 1998;27(7):401-403

24. Brandt L, Feino Cunha J, Weinreich Olsen A, Chilima B, Hirsch P, Appelberg R, et al. Failure of the Mycobacterium bovis BCG vaccine: some species of environmental mycobacteria block multiplication of BCG and induction of protective immunity to tuberculosis. Infect Immun. 2002;70(2):672-678

25. Igietseme JU, Black CM, Caldwell HD. Chlamydia vaccines: strategies and status. BioDrugs 2002;16(1):19-35

26. Jones TF, Moore W. The phthisis still with us. Tuberculosis: the white plague is not yet a ghost of the past. Tenn Med. 2001;94(2):62-63

27. Orme IM. Aging and immunity to tuberculosis: prolonged survival 
of old mice infected with Mycobacterium tuberculosis by adoptive immunization with memory-immune T lymphocytes. Cell Immunol. 1989;118(1):229-233

28. Hussein MZ, Amara AA. Case-by-case study using antibiotic-EDTA combination to control Pseudomonas aeruginosa. Pak J Pharm Sci. 2006;19(3):236-243

29. Ba AS. [The art of veterinary medicine and traditional pharmacopoeia in sub-Saharan Africa]. Rev Sci Tech. 1994;13(2):373-396

30. Rodas C, Mamani R, Blanco J, Blanco JE, Wiklund G, Svennerholm AM, et al. Enterotoxins, colonization factors and serotypes of enterotoxigenic (ETEC) strains isolated from hospitalized children with diarrhea in bolivia. Braz J Infect Dis. 2011;15(2):132-137

31. Drozdov SG. [Role of domestic animals in epidemiology of diphasic milk fever]. Zh Mikrobiol Epidemiol Immunobiol. 1959;30(4):102-108

32. Gresikova M, Rehacek J. [Isolation of the tick encephalitis virus from the blood and milk of domestic animals (sheep and cow) after infection by ticks of the family Ixodes ricinus L]. Arch Gesamte Virusforsch 1959;9:360-364

33. Hansen H, Okeke MI, Nilssen O, Traavik T. Recombinant viruses obtained from co-infection in vitro with a live vaccinia-vectored influenza vaccine and a naturally occurring cowpox virus display different plaque phenotypes and loss of the transgene. Vaccine. 2004;23(4):499-506

34. Agren JJ, Hanninen 00. Effect of moderate freshwater fish diet on erythrocyte ghost phospholipid fatty acids. Ann Med 1991;23(3):261263

35. Anesini C, Perez C. Screening of plants used in Argentine folk medicine for antimicrobial activity. J Ethnopharmacol. 1993;39(2):119-128

36. Ward LF. Why is water considered ghost-proof? Science 1885;5(100):2

37. American Academy of Pediatrics Committee on Infectious Diseases: Family history of convulsions in candidates for immunization with pertussis-containing vaccines (diphtheria, tetanus, pertussis) Pediatrics. 1987;80(5):743-744

38.Pertussis immunization; family history of convulsions and use of antipyretics--supplementary ACIP statement. MMWR Morb Morta Wkly Rep 1987;36:281

39. Baurain JF. [Important antitumoral immunity and a favorable clinical outcome in two patients receiving an autologous vaccine]. Bull Mem Acad R Med Belg. 2003;158(5-6):299-307

40. Giuliani G, Frezet D, Paggi GC, Varetti G. [Humoral immunity status against poliomyelitis in the Piedmont population 15 years after the introduction of vaccination with Sabin oral vaccine]. Ann Sclavo. 1982;24(1):5-15

41.medicine ho. Encyclopædia Britannica. Encyclopædia Britannica Student and Home Edition. Chicago: Encyclopædia Britannica 2013.

42. Experimental studies of vaccination, allergy, and immunity in tuberculosis: 1. Design for a research programme. Bull World Health
Organ. 1955;12(1-2):13-29

43. Hilleman MR. Hepatitis and hepatitis A vaccine: a glimpse of history. J Hepatol. 1993;18 Suppl 2:S5-10

44.Singh SV, Sohal JS, Singh PK, Singh AV. Genotype profiles of Mycobacterium avium subspecies paratuberculosis isolates recovered from animals, commercial milk, and human beings in North India. Int J Infect Dis. 2009;13(5):e221-227. doi: 10.1016/j.ijid.2008.11.022

45. Chen CC, Yang CK, Chen CY, Lee HC, Wang SM. Comparison of Rehydration Techniques for Fingerprinting the Deceased after Mummification. J Forensic Sci. 2016;62(1):205-208. doi: 10.1111/1556-4029.13237

46. Collini F, Andreola SA, Gentile G, Marchesi M, Muccino E, Zoja R. Preservation of histological structure of cells in human skin presenting mummification and corification processes by Sandison's rehydrating solution. Forensic Sci Int. 2014;244:207-212. doi: 10.1016/j. forsciint.2014.08.025

47. Amara AA. Kostenlos viral ghosts. bacterial ghosts microbial ghosts and more: Germany: Schuling Verlag; 2015

48. Amara AA. Lysozymes, Proteinase K, Bacteriophage E Lysis Proteins, and some Chemical Compounds for MGs Preparation: a Review and Food for Thought. SOJ Biochem. 2016;2(1):1-16. doi: 10.15226/2376$4589 / 2 / 1 / 00108$

49. Cavalieri D, McGovern PE, Hartl DL, Mortimer R, Polsinelli M. Evidence for S. cerevisiae fermentation in ancient wine. J Mol Evol. 2003;57 Suppl 1:S226-S232

50. Hailu Y, Hansen EB, Seifu E, Eshetu M, Ipsen R, Kappeler S. Functional and technological properties of camel milk proteins: a review. J Dairy Res. 2016;83(4):422-429

51. Khezri B, Chan YY, Tiong LY, Webster RD. Annual air pollution caused by the Hungry Ghost Festival. Environ Sci Process Impacts. 2015;17(9):1578-1586. doi: 10.1039/c5em00312a

52. Haase H, Fahmi A, Mahltig B. Impact of silver nanoparticles and silver ions on innate immune cells. J Biomed Nanotechnol. 2014;10(6):11461156

53. Sun P, Schwenk R, White K, Stoute JA, Cohen J, Ballou WR, et al. Protective immunity induced with malaria vaccine, RTS,S, is linked to Plasmodium falciparum circumsporozoite protein-specific CD4+ and CD8+ T cells producing IFN-gamma. J Immunol. 2003;171(12):69616967

54. Babu US, Balan KV, Bigley E, Pereira M, Black T, Olejnik N, et al. Effects of maternal silver acetate exposure on immune biomarkers in a rodent model. Food Chem Toxicol. 2016;98(pt B):195-200. doi: 10.1016/j. fct.2016.10.022

55. MarshallGoldberg M. The Immune system's newest weapons against cancer In "Cell Wars"(1st Ed.). Toronto, Canada; Collins Publishers 1988

56. Brudno IA, Bogomolova NN, Kolianova IS, Korchak OB, Andzhaparidze OG. ["Pharaoh" line culture of Japanese quail cells as a leukosis-free 
system for virus reproduction]. Vopr Virusol 1980:97

57. Rossi M. Homer and Herodotus to Egyptian medicine. Vesalius. 2010;Suppl:3-5

58. Thomas R. Greek medicine and Babylonian wisdom: circulation of knowledge and channels of transmission in the archaic and classical periods. Stud Anc Med. 2004;27:175-185

59. Kraut BH. Medicine and the arts. Histories: [excerpt] by Thucydides. Commentary. Acad Med. 2010;85(6):1008-1009. doi: 10.1097/ ACM.0b013e3181dc67d4

60.historiography. Encyclopædia Britannica. Encyclopædia Britannica Student and Home Edition. Chicago: Encyclopædia Britannica 2013.

61. Amara AA, Shibl A. Role of Probiotics in health improvement, infection control and disease treatment and management. Saudi Pharm J. 2015;23(2):107-114. doi: 10.1016/j.jsps.2013.07.001

62. Hosono A, Naga sawa Y. Fermented milk in the orient. In: (Eds.), Functions of Fermented Milk: Challenges for the Health Sciences. Elsevier Applied Science; London: UK: 1992;61-78.

63. Metchnikoff II, Mitchell, P. C, Nature of Man or Studies in Optimistic Philosophy. Whitefish Kessinger Publishing; MTUSA:1905

64. Metchnikoff, Elie. The Prolongation of Life: Optimistic Studies. New York \& London : G.P. Putnam's Sons; 1908.

65.Amara AA. In: Amara, A. (Ed.), Toward Healthy Genes. Schu" ling Verlage, Germany. 2012.

66. Amara AA. Back to natural fiber: wool color influences its sensitivity to enzymatic treatment. ScientificWorldJournal. 2012;2012:356239. doi: $10.1100 / 2012 / 356239$

67.Food and Agriculture Organization/World Health Organization (FAO/WHO). Health and nutritional properties of Probiotics in food including powder milk with live lactic acid bacteria, Report of a Joint FAO/WHO Expert Consultation on Evaluation of Health and Nutritional Properties of Probiotics in Food including powder milk with live lactic acid bacteria. 2001;1(4):1-56

68. Reid G, Sanders ME, Gaskins HR, Gibson GR, Mercenier A, Rastall R, et al. New scientific paradigms for Probiotics and prebiotics. J. Clin. Gastroenterol. 2003;37(2):105-118

69. Camelin A. [The special aspects of medicine in North Africa]. Rev Prat. 1960;10:391

70.Johnson RH, Corbett JL, Wilkinson RH. Desert journeys by Bedouin: sweating and concentration of urine during travel by camel and on foot. Nature. 1968;219:953-954. doi: 10.1038/219953a0

71. Abdulrahman AO, Ismael MA, Al-Hosaini K, Rame C, Al-Senaidy AM, Dupont J, et al. Differential Effects of Camel Milk on Insulin Receptor Signaling - Toward Understanding the Insulin-Like Properties of Camel Milk. Front Endocrinol (Lausanne). 2016;7:4. doi: 10.3389/ fendo.2016.00004

72. Alhaidar A, Abdel Gader AG, Mousa SA. The antiplatelet activity of camel urine. J Altern Complement Med. 2011;17(9):803-808. doi:

\subsection{9/acm.2010.0473}

73. Alimi D, Hajaji S, Rekik M, Abidi A, Gharbi M, Akkari H. First report of the in vitro nematicidal effects of camel milk. Vet Parasitol. 2016;228:153-159. doi: 10.1016/j.vetpar.2016.09.003

74.Al-Yousef N, Gaafar A, Al-Otaibi B, Al-Jammaz I, Al-Hussein K, Aboussekhra A. Camel urine components display anti-cancer properties in vitro. J Ethnopharmacol. 2012;143(3):819-825. doi: 10.1016/j.jep.2012.07.042

75. Ebaid H, Abdel-Salam B, Hassan I, Al-Tamimi J, Metwalli A, Alhazza I. Erratum to: Camel milk peptide improves wound healing in diabetic rats by orchestrating the redox status and immune response. Lipids Health Dis. 2017;16:43. doi: 10.1186/s12944-017-0421-x

76. Saltanat H, Li H, Xu Y, Wang J, Liu F, Geng XH. [The influences of camel milk on the immune response of chronic hepatitis B patients]. Xi Bao Yu Fen Zi Mian Yi Xue Za Zhi. 2009;25(5):431-433

77.Zibaee S, Hosseini SM, Yousefi M, Taghipour A, Kiani MA, Noras MR. Nutritional and Therapeutic Characteristics of Camel Milk in Children: A Systematic Review. Electron Physician. 2015;7(7):1523-1528. doi: $10.19082 / 1523$

78.embalming. Encyclopædia Britannica. Encyclopædia Britannica Student and Home Edition. Chicago: Encyclopædia Britannica 2013.

79. Agibalova LV. [Mechanism of the inhibitory effect of BCG vaccine on specific antitumor immunity in Syrian hamsters]. Biull Eksp Biol Med. 1978;86(9):358-360

80. Akamatsu H, Yamamoto M, Sekiya S, Yamamoto H, Kaneko I. [Living attenuated measles-virus vaccine. V. Protective affects and persistent immunity after inoculation with a living measles vaccine]. Nihon Ika Daigaku Zasshi. 1965;32(4):109-112

81. Bloch H. Edward Jenner (1749-1823). The history and effects of smallpox, inoculation, and vaccination. Am J Dis Child. 1993;147(7):772-774

82. Casey C, Vellozzi C, Mootrey GT, Chapman LE, McCauley M, Roper MH, et al. Surveillance guidelines for smallpox vaccine (vaccinia) adverse reactions. MMWR Recomm Rep. 2006;55(RR-1):1-16

83. Chen SC, Fynan EF, Greenberg HB, Herrmann JE. Immunity obtained by gene-gun inoculation of a rotavirus DNA vaccine to the abdominal epidermis or anorectal epithelium. Vaccine. 1999;17(23-24):31713176

84. Lombard M, Pastoret PP, Moulin AM. A brief history of vaccines and vaccination. Rev Sci Tech. 2007;26(1):29-48

85. Chevallier-Jussiau N. [Henry Toussaint and Louis Pasteur. Rivalry over a vaccine]. Hist Sci Med. 2010;44(1):55-64 